\title{
Auditory Attention: Time of Day and Type of School
}

\author{
Atenção Auditiva: Período do Dia e Tipo de Escola
}

\author{
Mirela Machado Picolini*, Damiane Stivanin**, Ariane Risatto Sampaio***, \\ Karina Krahembuhl Salvador*, José Roberto Pereira Lauris $* * * *$, Mariza Ribeiro Feniman $* * * *$.
}

\author{
* Speech therapist. Pupil Graduate School of Dentistry of Bauru, University of São Paulo. \\ ** Speech. Specializing in Human Communication Disorders at the Federal University of São Paulo, UNIFESP. \\ ***: Master of Speech Pathology, Faculty of Dentistry of Bauru, University of São Paulo, FOB / USP. Speech. \\ **** Doctor. Tenured Professor, Department of Pediatric Dentistry, Orthodontics and Public Health, Faculty of Dentistry of Bauru, University of São Paulo, FOB / USP. \\ ****** PhD. Tenured Professor, Department of Speech Pathology, Faculty of Dentistry of Bauru, University of São Paulo, FOB / USP. \\ Institution: Faculty of Dentistry of Bauru, University of São Paulo - FOB / USP. \\ Bauru / SP - Brazil. \\ Mail Address: Mariza Ribeiro Feniman - Dental School of Bauru - Department of Speech - Alameda Dr. Octavio Pinheiro Brisola, 9-75 - Vila Universitária - Bauru / SP \\ - Brazil - Zip code: 17012-900 - Caixa-Postal: 73 - Telephone: (+55 14) 3235-8256 - E-mail: feniman@usp.br \\ Financial Support: FAPESP - Foundation for Research Support of São Paulo. \\ Article received in January 3, 2010. Article accepted in March 21, 2010.
}

\section{SUMMARY}

Introduction:

The sustained auditory attention is crucial for the development of some communication skills and learning.

Objective:

To evaluate the effect of time of day and type of school attended by children in their ability to sustained auditory attention.

Method:

We performed a prospective study of 50 volunteer children of both sexes, aged 7 years, with normal hearing, no learning or behavioral problems and no complaints of attention. These participants underwent Ability Test of Sustained Auditory Attention (SAAAT). The performance was evaluated by total score and the decrease of vigilance. Statistical analysis was used to analysis of variance (ANOVA) with significance level of $5 \%(\mathrm{p} \leq 0.05)$.

Results:

The result set by the normative test for the age group evaluated showed a statistically significant difference for the errors of inattention $(p=0.041, p=0.027)$ and total error score $(p=0.033, p=0.024)$, in different periods assessment and school types, respectively.

Conclusion: Children evaluated in the afternoon and the children studying in public schools had a poorer performance

Keywords: on auditory attention sustained.

RESUMO

Introdução: attention, hearing, child, rating.

Objetivo:

Método:

A atenção auditiva sustentada é fundamental para o desenvolvimento de algumas habilidades comunicativas e aprendizagem.

Verificar o efeito do período do dia e o tipo de escola frequentada pela criança, em sua habilidade de atenção auditiva sustentada.

Foi realizado um estudo prospectivo com 50 crianças voluntárias de ambos os gêneros, na faixa etária de 7 anos, com audição normal, sem queixas escolares e/ou comportamentais e sem queixas de dificuldades de atenção. Estes participantes foram submetidos ao Teste da Habilidade de Atenção Auditiva Sustentada (THAAS). O desempenho foi avaliado pela pontuação total e pelo decréscimo de vigilância. Para a análise estatística foi utilizada a análise de variância (ANOVA), com nível de significância de $5 \%(\mathrm{p} \leq 0,05)$.

Resultados: $\quad$ O resultado normativo estabelecido pelo teste para a faixa etária avaliada demonstrou haver diferença estatisticamente significante para os erros de desatenção $(p=0,041 ; p=0,027)$ e pontuação total de erros ( $\mathrm{p}=0,033 ; \mathrm{p}=0,024)$, nos diferentes períodos de avaliação e tipos de escola, respectivamente.

Conclusão: As crianças avaliadas no período da tarde e as crianças que estudavam em escolas públicas apresentaram pior desempenho na habilidade de atenção auditiva sustentada.

Palavras-chave: atenção, audição, criança, avaliação. 


\section{INTRODUCTION}

Attention is a multimodal process, essential for development and learning (1) and the acquisition of language, not only on aspects relating to the field of linguistic structures, but also in the development of communication skills that allow the child to participate in a conversation, talk about a topic or tell a story (2).

The literature has shown that sustained attention and vigilance are the processes that characterize the attention abilities. Mediated by the prefrontal cortex in sustained attention is voluntary and controlled by the subject $(3,4)$. It is defined as the ability to maintain an efficient level of response to a target during a given period of time $(1,5,6)$, the organization of appropriate responses to signs and inhibition of inappropriate responses. The failure to detect the target stimulus (omission errors) reflects a lack of attention (7-9) as well as the presence of responses to a non-target stimulus, reflects the lack of inhibition (9). Children who have problems in sustaining attention, often have difficulty in inhibiting inappropriate responses to stimuli $(10,11)$.

Research has shown that the effects of age are greater than gender in sustained attention (12-14). However, the specific literature shows that when the ability to sustain attention has been studied, time of day is a factor that has been very little explored. Thus, some authors have reported data on sustained attention emphasizing school hours (11,12). Another study (15) found that the period of the day may be a possible source of variation in the child's ability to sustain attention.

Other variables such as socioeconomic status and type of school the child attends, whether from public or private schools, which could directly impact on the skills of attention, because children with low socioeconomic and studying in public schools have worse performance in tasks that require these skills $(16,17)$.

For professionals in health and education is essential to understand the effects of these variables in the skills of attention, since the sustained attention and vigilance, when altered, cause difficulty concentrating on the task at the expense of development and learning (2,18-22). Given this context, the objectives of this study were to assess the effect of length of day and type of school attended by children in their ability to sustained auditory attention.

\section{METHOD}

The prospective study was undertaken after approval by the Ethics in Human Research in the opinion paragraph. 011/2007, in 2007.

To compose the series, was conducted random contact with the public schools and particularly the city of Bauru (SP), and with officials and professionals from the Faculty of Dentistry of Bauru (FOB-USP), to invite their children belonging to aged 7 years to 7 years and 11 months to participate in this study.

After reading and signing the consent form the parents or guardians for the child underwent a directed interview in order to obtain personal data from children, information on hearing health, as regards the presence of a history of otitis, and hearing complaints of inattention, as well as academic and behavioral aspects.

Participants from this study 50 volunteer children of genders, 23 males and 27 females, aged from 7 years to 7 years and 11 months, enrolled in first grade of elementary school. For inclusion in the children should not complain school and / or behavioral difficulties or historical attention, comprehension problems, as well as complaints and / or hearing impairment.

To exclude the presence of any modification hearing and middle ear changes in the status of appraisal, visual inspection was made of the external ear canal with an otoscope Missouri brand, model TK007, specific interview, pure tone audiometry and tympanometry.

Pure tone audiometry was performed in a soundproof booth, using the Siemens SD 50 audiometer with TDH-39. Was investigated air hearing thresholds in the frequencies between 250, 500, 1000, 2000, 3000, 4000, 6000 and 8000 $\mathrm{Hz}$ The results of audiometry were analyzed according to the classification proposed by Northern and Downs (1991) (23), in which children who have hearing thresholds better than or equal to $15 \mathrm{~dB} \mathrm{HL}$, have normal hearing. Immittanciometry was made by the apparatus Tympstar GSI. Were included in the study subjects with type A tympanometric curve, according to the classification proposed by JERGER (1970) (24).

Participants were divided into two groups (group M and group T). Each group was composed of 25 children, taking into account the time of day that was performed to evaluate the proposal. The Group M was composed of children who underwent evaluation in the morning, between 09:00 and 11:30, and Group T in children who underwent evaluation in the afternoon, between 15:00 and 17:30.

Table 1 shows the distribution of children sampled.

The whole sample group was submitted to Test the 
Table I. Distribution of children in the study of the type of school and gender in groups.

\begin{tabular}{lccccc}
\hline \multirow{2}{*}{$\begin{array}{l}\text { Type of } \\
\text { school }\end{array}$} & \multicolumn{4}{c}{ Morning } & \multicolumn{2}{c}{ Period of the day } & Total \\
& Male & Female & Male & Female & \\
\hline Public & 7 & 6 & 7 & 10 & 30 \\
Private & 5 & 7 & 4 & 4 & 20 \\
\hline Total & 12 & 13 & 11 & 14 & 50 \\
\hline
\end{tabular}

Table 2. Mean values $(X)$ and standard deviation (SD) errors of inattention, impulsivity, total score of errors and decreased vigilance, considering the different periods.

\begin{tabular}{lcccc}
\hline $\begin{array}{l}\text { Period of } \\
\text { evaluation }\end{array}$ & $\begin{array}{c}\text { Listlessness } \\
\times(S D)\end{array}$ & $\begin{array}{c}\text { Impulsivity } \\
\times(S D)\end{array}$ & $\begin{array}{c}\text { Total of errors } \\
\times(S D)\end{array}$ & $\begin{array}{c}\text { Decrease of } \\
\text { Vigilance } \\
\times(S D)\end{array}$ \\
\hline Group M & $11.32(7.31)$ & $4.08(3.03)$ & $15.44(8.34)$ & $0.92(1.58)$ \\
Group T & $19.00(13.42)$ & $5.64(5.31)$ & $24.64(16.45)$ & $2.04(3.49)$ \\
\hline
\end{tabular}

Ability of Sustained Auditory Attention - SAAAT (13,14). The SAAAT is used to assess sustained auditory attention, in which the child should respond only to a specific auditory stimulus (target word), maintaining attention and concentration on the task for a period of time. Consists of the presentation and binaural diotic through earphones from a list of 100 monosyllabic words (containing 20 instances of the target word "not"). That list (recorded on CD standard) was presented six times without interruption. To be heard the target word; the child should raise a hand. The test was conducted in a soundproof booth with the aid of a CD player attached to a two-channel audiometer (SiemensSD 50) at an intensity of $50 \mathrm{dBNS}$, considering the average air hearing thresholds of the frequencies of 500, 1000 and $2000 \mathrm{~Hz}$, for each ear. The test lasts approximately 10 minutes. As for the result set by regulatory SAAAT, it is expected that a child of seven years to submit a score of $24.7(\mathrm{SD}=11.0)$ for the total score and a decrease of vigilance $\leq 8.0$ (14).

Statistical analysis was performed using analysis of variance (ANOVA) model with three fixed criteria. Adopted was $5 \%(\mathrm{p} \leq 0.05)$ value for rejection of the null hypothesis (Ho).

\section{RESULTS}

Based on the results obtained in SAAAT, was elaborated in Table 2 showing the distribution of mean values and standard deviations for the children sampled in different periods.

Table 3 shows mean values and standard deviations for the results achieved in implementing the SAAAT in different types of schools (public and private) attended by children.

Based on the values described in Table 4, analysis of variance (ANOVA) with significance level of 5\% (p $\leq 0.05$ ) showed a statistically significant difference for the errors of inattention $(p=0.041$ and $p=0.027)$ and total error score $(p=0.033$ and $p=0.024)$ in different periods of evaluation and types of schools, respectively. Given this evidence, it is noted that the children assessed in the afternoon and the children studying in public schools, had a poorer performance on auditory attention sustained.

\section{DISCUSSION}

The auditory attention is a cognitive process that allows the listener to focus selectively on the stimulus of interest, a stimulus while ignoring irrelevant competing, so the listener consciously selects the stimulus which he will watch and process its response $(1,5)$. 
Table 3. Mean values (X) and standard deviation (SD) errors of inattention, impulsivity, and total score of errors and decreased vigilance, considering the different types of schools.

\begin{tabular}{lcccc}
\hline $\begin{array}{l}\text { Type of } \\
\text { school }\end{array}$ & Listlessness & Impulsivity & Total of errors & $\begin{array}{c}\text { Decrease of } \\
\text { Vigilance }\end{array}$ \\
\hline Public & $\times(S D)$ & $\times(S D)$ & $\times(S D)$ & $\times(S D)$ \\
Private & $10,37(11,77)$ & $5,60(3,07)$ & $24,00(12,31)$ & $1,20(2,31)$ \\
\hline
\end{tabular}

Table 4. Results of analysis of variance (ANOVA) according to gender, type of school and the evaluation period.

\begin{tabular}{lcccc}
\hline Variable & Listlessness & Impulsivity & Total of errors & $\begin{array}{c}\text { Decrease of } \\
\text { Vigilance } \\
(p)\end{array}$ \\
\hline Gender & 0,591 & 0,816 & $(p)$ & 0,721 \\
$\begin{array}{l}\text { Type of school } \\
\text { Period of }\end{array}$ & 0,027 & 0,241 & 0,024 & 0,125 \\
evaluation & 0,041 & 0,190 & 0,033 & 0,067 \\
\hline
\end{tabular}

The auditory attention of students can be influenced by hearing impairment, causing impairment in attention and comprehension skills and thus compromising the performance and learning of these children. Thus, it became essential to realization of audiometry and impedance prior to application of SAAAT (19).

By comparing the results of this study, described in Table 4, referred to specific literature $(13,14,20,25,26)$, no statistically significant difference observed in the comparison between the genders is consistent. However, these data contradict other study (27), in which the genre has proved to be an important variable in the skills of attention.

Regarding the type of school (public or private), children who attend public school had a score value increased to a total score of errors. The statistically significant difference found when comparing public and private schools is evident in other studies $(16,17)$, it was found lower performance of attention abilities in children who were studying in public schools, since they live in environments of communication less encouraging.

As described in Tables 2 and 3, it is possible to observe a greater number of errors of inattention compared to impulsivity, both during the day, as the type of school. These data corroborate findings in other studies $(20,25)$. The observation of this data is important for planning therapeutic intervention, since the compensatory strategy used for intervention should be dependent on the type of error made by the child.

The skill of attention, according to our data, appears to be influenced by time of day because the children studied in the afternoon (Group T) had a score above the expected result for the total score of errors. As for the decrease in vigilance, the score obtained is within normal parameters for both groups (20). Thus, these children showed inferior performance, becoming more careless when compared those evaluated in the morning. Inattention is displayed by children who have difficulty decoding lexical, which often take in processing the stimulus and completely lose the word or show a delayed response (5).

The hearing process is a series of processes involved in listening skills, including attention, memory, sound detection, location, figure-ground, among others (28). The literature $(21,29)$ reports that children with learning difficulties, have poorer performance on alertness, suggesting delayed maturation of auditory processing skills.

The association between the ability of attention and learning raised by some authors $(1,2,18,21,29)$, shows that academic performance is strongly affected when the child has no ability to concentrate to a target stimulus, for a given 
period of time. This attention deficit will affect these children in the communication skills necessary for the acquisition of oral language as well as in written language acquisition $(2,22)$.

Importantly, the identification of difficulties in processing auditory verbal and nonverbal children in preschool and school has affirmed its importance in academic foundations, maturational, psychological, and economic. Early identification of children with serious skills auditory information processing reduces time and costs of intervention (30).

Thus, considering that one of the leading causes of school failure among children is the lack of attention (20), as this is essential for learning new skills, oral and written communication, and learning as described above, to assess the sustained auditory attention ability is of utmost importance.

In this study, the comparative assessment of different periods of the day allows the speech therapist to determine the period that the child has a higher level of sustained auditory attention, enabling a study of the therapeutic plan for the rehabilitation process is enhanced. In this context, it is still the professional guidance to parents and guardians about the school term attended by their children, because it may encourage the academic performance of children with this skill.

The audiologist also should note the type of school attended by children, public or private, as this variable may also influence the ability of sustained auditory attention. They need to be carried out guidelines for teachers and educators on the auditory attention, as well as activities that can stimulate the development and maintenance of this ability during the class period in order to favor the development of oral language, writing and learning of these students.

\section{CONCLUSION}

The children assessed in the afternoon and those who study in public schools had a poorer performance on sustained auditory attention, suggesting that the length of day and type of school may be a possible source of variation in the child's ability to sustain attention hearing.

\section{BIBLIOGRAPHICAL REFERENCES}

1. Gomes H, Molholm S, Christodoulou C, Ritter W, Cowan $\mathrm{N}$. The development of auditory attention in children. Front Biosci. 2000, 1(5):D108-20.
2. Silva RA, Souza LAP. Aspectos lingüísticos e sociais relacionados ao transtorno de déficit de atenção/ hiperatividade. Rev CEFAC. 2005, 7(3):295-9.

3. Weintraub S. Neuropsychological assessment of mental state. In: Mesulam MM. (2Ed.), Principles of Behavioral and Cognitive Neurology. Oxford Univ. Press, New York, 2000, pp. 121-173.

4. Choudhury N, Gorman KS. The relationship between sustained attention and cognitive performance in 17-24month old toddlers. Inf Child Dev. 2000, 9:127-46.

5. Medwetsky L. Central auditory processing. In: Katz J, Burkard RF, Medwetsky L., eds. Handbook of Clinical Audiology. Baltimore, Williams \& Wilkins, 2002. p.495-509.

6. Ward, A. Attention-A Neuropsychological Perspective. Psychology Press, Hove-New York, 2004, p. 133.

7. Corkum PV, Siegel LS. Is the continuous performance task a valuable research tool for use with children with Attention Deficit Hyperactivity Disorder? J Child Psychol Psychiatry. 1993, 34(7):1217-39.

8. Chhabildas N, Pennington BF, Willcutt EG. A comparison of the neuropsychological profiles of the DSM-IV subtypes of ADHD. J Abnorm Child Psychol. 2001, 9(6):529-40.

9. Berwid OG, Curko Kera EA, Marks DJ, Santra A, Bender HA, Halperin JM. Sustained attention and response inhibition in young children at risk for Attention Deficit/Hyperactivity Disorder. J Child Psychol Psychiatry. 2005, 46(11):121929.

10. Hooks K, Milich R, Lorch EP. Sustained and selective attention in boys with attention de ficit hyperactivity disorder. J Clin Child Psychol. 1994, 23:69-77.

11. Suess PE, Porges SW, Plude DJ. Cardiac vagal tone and sustained attention in school-age children. Psychophysiology. 1994, 31(1):17-22.

12. Seidel WT, Joschko M. Evidence of difficulties in sustained attention in children with ADDH. J Abnorm Child Psychol 1990, 18:217-29.

13. Feniman MR. Aplicação do teste de atenção auditiva THAAS em crianças ouvintes normais [tese]. Bauru (SP): USP; 2004.

14. Feniman MR, Ortelan RR, Lauris JRP, Campos CF, Cruz MS. Proposta de instrumento comportamental para avaliar a atenção auditiva sustentada. Rev Bras Otorrinolaringol. 2007, 73(4):523-7. 
15. Anderson KJ, Revelle W. Impulsivity and time of day: is rate of change in arousal a function of impulsivity? J Pers Soc Psychol. 1994, 67(2):334-44.

16. Nogueira GL, Castro A, Naveira L, Nogueira-Antuñano F, Natinzon A, Gigli SL, et al. Evaluation of the higher brain functions in 1 st and 7 th grade schoolchildren belonging to two different socioeconomic groups. Rev Neurol. 2005, 40(7):397-406.

17. Rosselli M, Matute E, Ardila A. Neuropsychological predictors of reading ability in Spanish. 2006, 42(4):202-10.

18. Marco Marzocchi G, Ornaghi S, Barboglio S. What are the causes of the attention deficits observed in children with dyslexia? Child Neuropsychol. 2009, 26:1-15.

19. Araújo AS, Moura JR, Camargo LA, Alves W. Avaliação auditiva em escolares. Rev Bras Otorrinolaringol. 2002, 68(2):263-6.

20. Lemos ICC. Habilidade de atenção auditiva em crianças de sete anos com fissura labiopalatina: estudo comparativo [dissertação]. Bauru (SP): Faculdade de Odontologia de Bauru, Universidade de São Paulo; 2007.

21. Sauer L, Pereira LD, Ciasca SM, Pestun M, Guerreiro MM. Processamento auditivo e spect em crianças com dislexia. Arq Neuropsiquiatr. 2006, 64(1):108-11.

22. Gomes $\mathrm{H}$, Wolfson V, Halperin JF. Is there a selective relationship between language functioning and auditory attention in children? J Clin Exp Neuropsychol. 2007, 29(6):660-8.
23. Northern JL, Downs M. Hearing in children. 4th ed. Baltimore: Willians Wilkins; 1991.

24. Jerger, J. F. Clinical experience with impedance audiometry. Arch. Otolaryngol. 1970, 92:311-324.

25 Keith RW. ACPT: Auditory continuous performance test. San Antonio: Psychological Corporation. 1994.

26. Mondelli MFCG. Desemprenho de crianças com perda auditiva leve no Teste de Habilidade de Atenção Auditiva Sustentada - THAAS [tese]. Bauru (SP): Hospital de Reabilitação de Anomalias Craniofaciais, Universidade de São Paulo; 2007.

27. Groot AS, de Sonneville LM, Stins JF, Boomsma DI. Familial influences on sustained attention and inhibition in preschoolers. J Child Psychol Psychiatry. 2004, 45(2):30614.

28. Cavadas M, Pereira LD, Mattos P. Efeito do metilfenidato no processamento auditivo em crianças e adolescentes com transtorno do déficit de atenção/hiperatividade. Arq Neuropsiquiatr. 2007, 65(1):138-43.

29. Neves IF, Schochat E. Maturação do processamento auditivo em crianças com e sem dificuldades escolares. Pro Fono. 2005, 17(3):311-20.

30. Kelly D. A rationale for screening for central auditory processing difficulties at the kindergarten and second-grade levels: considerations for the Speech-Language Pathologist. [acesso em 20 de novembro de 2005]. Disponível em: http:/ /www.ncapd.org/ 